BIOMEDICAL AND BIOSOCIAL ANTHROPOLOGY
$\begin{gathered}\text { Official Journal of the International Academy } \\ \text { of Integrative Anthropology } \\ \text { journal homepage: http://bba-journal.com }\end{gathered}$

\title{
Peculiarities of hormonal homeostasis in perimenopausal and postmenopausal women with menopausal disorders
}

Vaskiv O.V., Grigorenko A.P., Horbatiuk O.G., Shatkovska A.S., Binkovska A.N.

National Pirogov Memorial Medical University, Vinnytsya, Ukraine

\section{ARTICLE INFO}

Received: 22 March 2019

Accepted: 26 April 2019

UDC: $618.1-007: 616.018 .2$

\section{CORRESPONDING AUTHOR}

e-mail: gynecology_fpo@vnmu.edu.ua Vaskiv O.V.
According to WHO, now on the planet $46 \%$ of women are over the age of 45 years, among women in Ukraine - this is almost half (13.2 million). Of these, 46-68 \% suffer from climacteric syndrome. An increase in the duration of a healthy life and prolongation of the age of working capacity acquire not only medical, but also socio-economic significance, both in Ukraine and in other European countries. Therefore, the aim of the study was a comprehensive (involving pituitary, ovarian, adrenal and thyroid hormones) hormonal examination of women of peri- and postmenopausal age with menopause syndrome to identify the most likely hormonal predictors of this pathology. For this purpose, 64 women of perimenopausal and postmenopausal age with menopause and 42 healthy women of the same age categories had a study of the concentration of pituitary (LH, FSH, prolactin), ovarian hormones (estradiol, progesterone, testosterone), thyroid hormones (TSH, triiodothyronine (T3), thyroxine (T4)) and adrenal glands (DHEA$s$, cortisol) in blood plasma. Hormones were determined using a set of test systems from "Immunotech" (Czech Republic-France) using the radio-immune method. Comparisons of the quantitative data of the two related groups (before and after treatment) were made using Wilcoxon signed rank test. When differences were detected, pairwise group comparisons were performed using the Mann-Whitney test. In women of perimenopausal and postmenopausal age with menopause syndrome, compared with healthy women of the same age groups, a significant increase in gonadotropin levels (LH by 3.7 and 3.0 times, respectively; FSH by 1.6 and 1.9 times) and a decrease indicator of prolactin in 1.5 and 1.2 times; estradiol 1.2 and 2.2 times and testosterone 2.9 and 2.4 times. A significant decrease in progesterone by 1.9 times occurred only in the group of postmenopausal women with menopause syndrome. In women of perimenopausal and postmenopausal age of the main group, a significant decrease was found in comparison with the control of DHEA-s levels by 1.3 times and 2.2 times, respectively; cortisol 1.2 and 2.0 times; TSH is 2.6 times and 2.0 times, respectively, however, thyroxine tended to increase (the probability $p<0.05$ was valid only for women of perimenopausal age). Thus, in postmenopausal women with menopausal syndrome, hormonal imbalance is more pronounced, indicating a deep atrophy of hormonedependent tissue receptors and, as a result, a deepening of involutive processes.

Keywords: hormonal homeostasis, perimenopause, postmenopause, menopausal disorders.

\section{Introduction}

The problem of disorders in the hormone-dependent organs and systems of the body of the woman during the period of perimenopause and post-menopause is becoming more urgent, since it is primarily concerned with the quality of life of women during their professional maturity and the greatest activity in family and public life $[6,7,15$, 19].

An analysis of the age structure of the population in recent years shows that Ukraine is in a state of deep demographic crisis caused by depopulation, an increase in the share of elderly people, and a decrease in the average life expectancy $[7,18,19]$. This has a negative impact on the development of productive forces, the level of well-being of people and the economic situation in the country [18, 19].

According to $\mathrm{WHO}, 46 \%$ of women are now over the 
age of 45 (peri and post-menopausal) on the planet already, among women of Ukraine it is 13.2 million, that is almost half $[5,18,19]$, therefore the increase in life expectancy and prolongation age of working capacity is gaining not only medical but also socio-economic importance, both in Ukraine and in other European countries.

Systemic irreversible changes that develop in the body of a woman during menopause due to progressive estrogen deficiency $[7,12,13,14,17]$, dictate the need to find effective methods for their prediction, as well as the introduction of alternative methods of prevention and treatment of menopausal disorders $[4,7,11,18]$.

It is very difficult to predict the individual age of menopausal disorders, since ovarian failure is a complex multifactorial and lengthy process. During menopause, the background of age-related changes in the body is dominated by involutionary processes in the reproductive system $[6,17,20]$.

The gradual involution of the ovarian parenchyma is accompanied by a decrease in the production of sex hormones (estradiol, progesterone and androgens) [1, 3, 16] Due to the fact that hormonal regulation in the body occurs on the principle of feedback, due to the decreased level of estrogen in the pituitary gland, there is an increase in the production and release of gonadotropic hormones [2, 4, 7, 10].

The purpose of our study was a comprehensive (involving pituitary, ovarian, adrenal, and thyroid hormones) hormonal examination of women of peri- and postmenopausal age with climacteric syndrome to identify hormonal predictors of menopausal disorders.

\section{Materials and methods}

We monitored 64 perimenopausal and postmenopausal women with menopausal mid- and severecourse disorders (main group). The control group included 42 healthy women of the same age categories.

Women of the main age group were distributed as follows: in the perimenopausal age (46-50 years) were $21(32.8 \%)$ women and in the postmenopausal (51-65 years) - 43 $(67.2 \%)$ women. The control group consisted of 21 perimenopausal women (46-50) and 21 postmenopausal women without menopause disorders (51-65 years). By the severity of menopausal disorders, women of the main group were distributed as follows: severe disease was reported in 17 (38.6 \%) women, medium-severe in 27 (61.4 \%) women. All severe forms of the disease occurred exclusively in postmenopausal women. Moreover, the duration of menopause in such women ranged from 1 to 2 years.

Selection of individuals for inclusion in the study was performed on the basis of detailed anamnesis, complaints and examination using standard clinical and laboratory methods of investigation.

Investigation of the concentration of pituitary-ovarian hormones ( $\mathrm{LH}, \mathrm{FSH}$, prolactin, estradiol, progesterone, testosterone), thyroid (TSH, triiodothyronine (T3), thyroxine (T4)) and adrenal glands (DHEA-s, cortisol) in the blood plasma was determined by radioimmunoassay using "Immunotech" (Czech-France) test systems kits. All studies were performed on the basis of the enzyme immunoassay laboratory of the Municipal Enterprise "Khmelnitsky City Perinatal Center". All patients received the prior consent of the study.

Comparisons of the quantitative data of the two related groups (before and after treatment) were made using the Wilcoxon nonparametric paired-sample criterion. When differences were detected, pairwise group comparisons were performed using the Mann-Whitney test. Differences were significant at $p<0.05$ levels $[8,9]$.

\section{Results}

In perimenopausal women, an increase in the concentration of gonadotropic hormones was found to be characteristic of menopause, and in women with climacteric syndrome this increase was significantly greater than in healthy women of the same age (Fig. 1). Thus, the LH level was increased in 3.7 times as compared to the control $(35.71 \pm 3.57 \mathrm{mlU} / \mathrm{ml}$ and $9.640 \pm 1.050 \mathrm{mIU} / \mathrm{ml}$, respectively, $\mathrm{p}<0.05), \mathrm{FSH}-1.59$ times $(13.68 \pm 1.040 \mathrm{mIU} / \mathrm{ml}$ and $8,560 \pm 1.080 \mathrm{mlU} / \mathrm{ml}$, respectively, $\mathrm{p}<0.05)$, the $\mathrm{LH} / \mathrm{FSH}$ ratio increased 2.34 -fold $(2.610 \pm 0.470$ and $1.126 \pm 0.130$, $p<0.05$, respectively). At the same time, prolactin decreases in 1.5 times (respectively $154.0 \pm 17.2 \mu \mathrm{IU} / \mathrm{ml}$ and $233.8 \pm 23.1 \mu \mathrm{lU} / \mathrm{ml}, \mathrm{p}<0.05)$, estradiol -1.2 times (respectively $104.5 \pm 9.1 \mathrm{ng} / \mathrm{l}$ and $126.3 \pm 10.7 \mathrm{ng} / \mathrm{l}, \mathrm{p}<0.05$ ), testosterone - 2.9 times (respectively $0.187 \pm 0.020 \mathrm{ng} / \mathrm{ml}$ and $0.539 \pm 0.090 \mathrm{ng} / \mathrm{ml}, \mathrm{p}<0.05)$. Progesterone concentration was at the control group level $(0.358 \pm 0.040$ $\mathrm{ng} / \mathrm{ml}$ and $0.379 \pm 0.030 \mathrm{ng} / \mathrm{ml}$, respectively, $\mathrm{p}>0.05)$.

Postmenopausal women revealed the following (Fig. 2): LH level increased 3-fold compared to control $(64.18 \pm 3.31 \mathrm{mlU} / \mathrm{ml}$ and $21.13 \pm 1.06 \mathrm{mlU} / \mathrm{ml}$, respectively, $\mathrm{p}<0.05$ ), $\mathrm{FSH}$ in 1.9 times (respectively $42.21 \pm 0.40 \mathrm{mlU} / \mathrm{ml}$ and $22.30 \pm 1.09 \mathrm{mIU} / \mathrm{ml}, \mathrm{p}<0.05)$, the $\mathrm{LH} / \mathrm{FSH}$ ratio

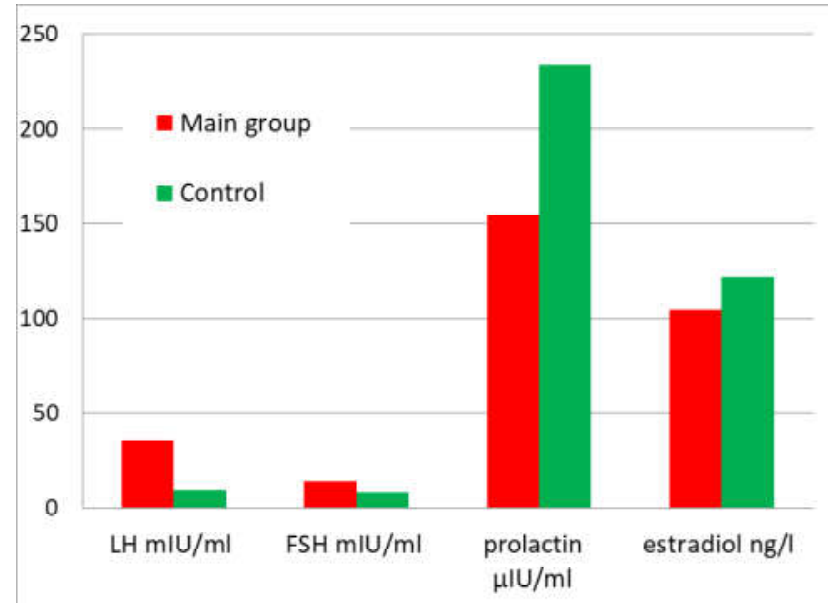

Fig. 1. Comparison of indicators of hormonal homeostasis of perimenopausal women with climacteric syndrome with healthy women of the same age. 


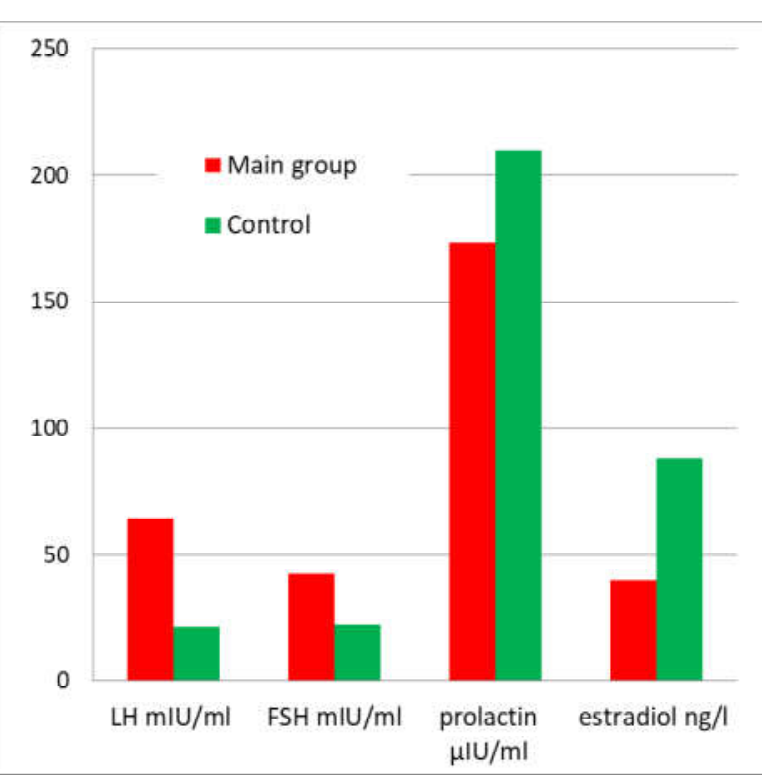

Fig. 2. Comparison of hormonal homeostasis indices of postmenopausal women with climacteric syndrome with healthy women of the same age.

Table 1. Thyroid function in women with climacteric syndrome in perimenopausal and postmenopausal age $(\mathrm{M} \pm \mathrm{m})$.

\begin{tabular}{|c|c|c|c|}
\hline Hormones & $\begin{array}{l}\text { Main group } \\
(n=21-43)\end{array}$ & $\begin{array}{l}\text { Control } \\
(n=21)\end{array}$ & $\mathrm{p}$ \\
\hline \multicolumn{4}{|l|}{ Perimenopausal age } \\
\hline TSH (mlU/L) & $0.840 \pm 0.130$ & $1.420 \pm 0.340$ & $<0.05$ \\
\hline Triiodothyronine (T3) (nmol/L) & $1.860 \pm 0.100$ & $2.080 \pm 0.150$ & $>0.05$ \\
\hline Thyroxine (T 4) (nmol/L) & $107.9 \pm 1.7$ & $87.38 \pm 1.82$ & $<0.05$ \\
\hline \multicolumn{4}{|l|}{ Postmenopausal age } \\
\hline TSH (mlU/L) & $0.540 \pm 0.100$ & $1.090 \pm 0.110$ & $<0.05$ \\
\hline Triiodothyronine (T 3) (nmol/L) & $1.830 \pm 0.050$ & $1.970 \pm 0.090$ & $>0.05$ \\
\hline Thyroxine (T 4) (nmol/L) & $90.18 \pm 2.04$ & $85.00 \pm 3.92$ & $>0.05$ \\
\hline
\end{tabular}

Table 2. Functional state of adrenal glands in women with climacteric syndrome in perimenopausal and postmenopausal age $(\mathrm{M} \pm \mathrm{m})$.

\begin{tabular}{|c|c|c|c|}
\hline Hormones & $\begin{array}{c}\text { Main group } \\
(\mathrm{n}=21-43)\end{array}$ & $\begin{array}{c}\text { Control } \\
(\mathrm{n}=21)\end{array}$ & $\mathrm{p}$ \\
\hline \multicolumn{5}{|l|}{} \\
\hline Perimenopausal age & $5.450 \pm 0.260$ & $6.920 \pm 0.240$ & $<0.05$ \\
\hline DHEA-s (nmol/L) & $378.8 \pm 7.0$ & $440.0 \pm 12.3$ & $<0.05$ \\
\hline Cortisol (nmol/L) & $1.860 \pm 0.110$ & $4.060 \pm 0.330$ & $<0.05$ \\
\hline Postmenopausal age & $189.2 \pm 10.7$ & $385.6 \pm 11.7$ & $<0.05$ \\
\hline DHEA-s (nmol/L)
\end{tabular}

increased in 1.4 times $(1.520 \pm 0.220$ and $0.950 \pm 0.130$, $\mathrm{p}<0.05$, respectively). The level of prolactin decreased in 1.2 times (respectively $173.3 \pm 8.5 \mu \mathrm{lU} / \mathrm{ml}$ and $210.1 \pm 32.1$ $\mu \mathrm{IU} / \mathrm{ml}, \mathrm{p}<0.05$ ), estradiol - 2.2 times (respectively $39.93 \pm 2.71 \mathrm{ng} / \mathrm{ml}$ and $87.93 \pm 14.10 \mathrm{ng} / \mathrm{ml}, \mathrm{p}<0.05)$, progesterone - 1.9 times (respectively $0.147 \pm 0.030 \mathrm{ng} / \mathrm{ml}$ and $0.280 \pm 0.040 \mathrm{ng} / \mathrm{ml}, \mathrm{p}<0.05$ ), testosterone -2.4 times (respectively $0.158 \pm 0.120 \mathrm{ng} / \mathrm{ml}$ and $0.377 \pm 0.200 \mathrm{ng} / \mathrm{ml}$, $\mathrm{p}<0.05)$

The functional status of the thyroid gland $(\mathrm{TSH}$, triiodothyronine (T3) and thyroxine (T4)) and adrenal glands (DHEA-c, cortisol - involved in the functioning of the reproductive system) in women of perimenopausal and postmenopausal age are presented in Table 1 and 2 .

\section{Discussion}

In the available literature, there is no comparison of hormonal changes in the age range, and between groups of women with and without climacteric syndrome, and are not involved in the study of thyroid and adrenal hormones $[11,14,17,20]$.

If we compare hormone indices in women of the main group of perimenopausal age and control, we should note a significant increase in $\mathrm{LH}$ and $\mathrm{FSH}$ levels, $\mathrm{LH} / \mathrm{FSH}$ ratio, and a significant decrease in estradiol, prolactin, and total testosterone [1, 3]. No significant increase in progesterone was observed. These indicators are correlated with the data of many researchers $[4,5,6,7]$.

Postmenopausal women, due to the atrophy of the receptor apparatus of hormone-dependent organs, exacerbate the involutive processes, which is certainly consistent with the literature [1, 2, 3, 15]. However, we have found that ovarian and pituitary hormone depletion in women with climacteric syndrome is much deeper than in healthy postmenopausal women. In perimenopausal and postmenopausal periods, levels of gonadotropins increase and prolactin, estradiol, progesterone and testosterone levels decrease [2, 4], but in women with climacteric syndrome these changes are more pronounced.

Analysis of hormonal parameters of thyroid function in women with climacteric syndrome of perimenopausal and postmenopausal age showed that TSH levels were significantly lower than controls, however, thyroxine tended to increase $(p<0.05$ was valid only for women of perimenopausal age).

Analysis of the functional state of the adrenal glands in women with climacteric syndrome perimenopausal age showed that the level of DHEA-c in women of perimenopausal age was lower than the control 1.3 times $(p<0.05)$, and the level of cortisol was 1.2 times lower $(p<0.05)$. Postmenopausal women also experienced a 2.2fold decrease in DHEA-s compared to controls, and a 2.0fold decrease in cortisol $(p<0.05)$.

Thus, perimenopausal and postmenopausal women with climacteric syndrome have increased levels of gonadotropins and decreased levels of prolactin, estradiol, progesterone, and testosterone compared with healthy women of the same age groups. Moreover, in postmenopausal women, these changes are significantly more pronounced than in the perimenopause, indicating a deep atrophy of receptors of hormone-dependent tissues and, as a consequence, the deepening of involutional processes.

A comparative study of the density of the receptor 
apparatus in estrogen-dependent organs in peri and postmenopausal women with and without climacteric syndrome is promising.

\section{Conclusions}

1. In perimenopausal and postmenopausal women with climacteric syndrome, there are increased $(p<0.05)$ levels of gonadotropins - LH in 3.7 and 3.0 times, respectively, and $\mathrm{FSH}$ in 1.6 and 1.9 times; and decreased $(p<0.05)$ prolactin levels by 1.5 and 1.2 times, estradiol by 1.2 and 2.2 times, and testosterone by 2.9 and 2.4 times, respectively, compared with healthy women of similar age groups. A significant decrease in progesterone 1.9 times occurred only in the group of postmenopausal women with climacteric syndrome.

2. Women with climacteric syndrome of perimenopausal and postmenopausal age showed a significant decrease in TSH compared to similar controls: 2.6 times and 2.0

\section{References}

[1] Baber, R. J., Panay, N., Fenton, A., \& the IMS Writing Group (2016). IMS Recommendations on women's midlife health and menopause hormone therapy. Climacteric, 19(2), 109-150. http://dx.doi.org/10.3109/13697137.2015.1129166

[2] Beck, V., Unterrieder, E., Krenn, L., Kubelka, W., \& Jungbauer, A. (2003). Comparison of hormonal activity (estrogen, androgen, and progestin) of standardized plant extract for large scale use in hormone replacement therapy. Journal of Steroid Biochemistry \& Molecular Biology, 1831, 1-10. doi: 10.1016/s0960-0760(03)00034-7

[3] Grigorenco, A. P., Shymanska-Horbatyuk, O. G., Shatkovska, N. S., \& Garbuziuk, V. V. (2013). Hormonal homeostasis in women with prolapse of the pelvic organs. Collection of scientific works of the Association of obstetricians and gynecologist of Ukraine. Kyiv: Poligraf plus.

[4] Horbatiuk, O. H. (2017). Method for correction of climacteric disorders in women of peri- and postmenopausal age. Medical practice, 5-6, 121-125. https://vrachebnoedelo.com/index.php/ journal/issue/view/42/5-6-2017-PDF

[5] Horbatiuk, O. H., Shatkovska, A. S., \& Hryhorenko, A. P. (2016). Menopausal syndrome: a training manual for physicians. Vinnitsa. VNMU n.a. Pirogov.

[6] Horbatiuk, O., Binkovska, A., Herych O., Ropotan, A., Zhylko, N., Mandziy, I., \& Buleza, I. (2017). Using micronized progesterone for treatment of premenopausal age women suffering from severe premenstrual syndrome. Current Issues in Pharmacy and Medical Sciences, 30(3), 138-141. doi: 10.1515/cipms-2017-0025

[7] Horbatiuk, O. H., Hryhorenko, A. P., Shatkovska, A. S., Binkovska, A. M., Onyshko, V. Yu., \& Gerich, O. Kh. (2017). Optimization of the vegetative-forensic and neuropsychiatric destruction of the clinical syndrome. Zaporizhzhya medical journal, 19(4), 482-486. doi: https://doi.org/10.14739/23101210.2017.4.105110

[8] Kochetov, A. G., Lianh, O. V., Masenko, V. P., Zhyrov, I. V., Nakonechnykov, S. N., \& Tereshchenko, S. N. (2012). Methods of statistical processing of medical data: guidelines. Moscow: Ministry of Health of the Russian Federation, Russian Cardiology Research and Production Complex. https:// www.fedlab.ru/upload/medialibrary/e05/_.pdf

[9] Kyrianov, B. F., \& Tokmachjov, M. S. (2009). Mathematical times, respectively; however, thyroxine tended to increase ( $p<0.05$ was only valid for perimenopausal women).

3. Analysis of the functional state of the adrenal glands in women with climacteric syndrome of perimenopausal age showed a significant decrease in the level of DHEA-s 1.3 times and the level of cortisol 1.2 times relative to control $(p<0.05)$. In postmenopausal age, there was a 2.2 -fold decrease in DHEA-s compared with controls $(p<0.05)$; cortisol - 2.0 times $(p<0.05)$.

4. In postmenopausal women with climacteric syndrome, hormonal imbalance is more pronounced, indicating profound atrophy of hormone-dependent tissue receptors and, as a consequence, deepening of involutive processes.

5. The deep imbalance of hormonal indices of the pituitary-ovarian axis and adrenal glands may be a predictor of menopausal disorders in women of peri- and postmenopausal age.

Models in Health Care: A Tutorial. Veliky Novgorod: NovSU Yaroslav the Wise. ISBN: 978-589896-357-6

[10] Manukhyn, I. B., Tumylovych, L. G., Hevorkian, M. A., \& Manukhyna, E. I. (2016). Gynecological endocrinology. Clinical Lectures: A Guide. (4th ed., Revised). Moscow: GEOTAR Media.

[11] Namiki, T., Sato, H., Matsumoto, Y., Kakikura, H., Ueno, K., Chino, A., ... \& Kihara, M. (2014). Identification of a predictive biomarker for the beneficial effect of keishibukuryogan, a Kampo (Japanese traditional) medicine, on patients with climacteric syndrome. Evidence-Based Complementary and Alternative Medicine, 2014, 962109. doi: 10.1155/2014/962109

[12] North American Menopause Society. (2013). Management of symptomatic vulvovaginal atrophy: 2013 position statement of The NorthAmerican Menopause Society. Menopause, 20(9), 888-902. doi: 10.1097/GME.0b013e3182a122c2

[13] Nyirjesy, P. (2007). Postmenopausal vaginitis. Current Infectious Disease Reports, 9(6), 480-484. doi: 10.1007/s11908-0070073-5

[14] Palacios, S. (2009). Managing urogenital atrophy. Maturitas, 63(4), 315-318. doi: 10.1016/j.maturitas.2009.04.009

[15] Pereira, R. I., Casey, B. A., Swibas, T. A., Erickson, C. B., Wolfe, P., \& Van Pelt, R. E. (2015). Timing of estradiol treatment after menopause may determine benefit or harm to insulin action. The Journal of Clinical Endocrinology \& Metabolism, 100(12), 4456-4462. doi: 10.1210/jc.2015-3084

[16] Scott, J. R., Gibbs, R. S., Karlan, B. Y., \& Haney, A. F. (Ed). (2003). Danforth's Obstetrics and Gynecology (9th edition). Philadelphia - New York: Lippincott Williams \& Wilkins Publishers. ISBN 10: 0781737303

[17] Studd, J. (2012). Spotlight on severe premenstrual syndrome and bipolar disorder: a frequent tragic confusion. Climacteric, 14, 602. doi: $10.1258 / \mathrm{mi} .2012 .012018$

[18] Tatarchuk, T. F., Avramenko, N. V., Bulavenko, O. V., Habal, V. A., Burlaka, O. V., Hanzhyi, I. Yu., ... \& Hiulmamedova, I. D. (2016). National consensus on the management of patients in menopause. Reproductive endocrinology, 27(1), 8-25. https:/ /doi.org/10.18370/2309-4117.2016.27.8-25

[19] Verner, I. E. (2019). Regions of Ukraine 2019: Stat. Collection of the State Statistics Committee of Ukraine. http:// www.ukrstat.gov.ua/druk/publicat/kat_u/2019/zb/12/ 
zb_ru1ch2019.pdf

[20] Weiser, M. J., Foradori, C. D., \& Handa, R. J. (2008). Estrogen receptor beta in the brain: from form to function. Brain
Research Reviews, 57, 309-320. doi: 10.1016/ j.brainresrev.2007.05.013

\section{ОСОБЛИВОСТІ ГОРМОНАЛЬНОГО ГОМЕОСТАЗУ У ЖІНОК ПЕРИМЕНОПАУЗАЛЬНОГО ТА ПОСТМЕНОПАУЗАЛЬНОГО ВІКУ 3 КЛІМАКТЕРИЧНИМИ ПОРУШЕННЯМИ \\ Васьків О.В., Григоренко А.П., Горбатюк О.Г., Шатковська А.С., Біньковська А.М.}

За даними ВООЗ зараз на планеті 46 \% жінок перебувають у віці старше 45 років, серед жінок України - це майже половина (13,2 мільйона). 3 них 46-68 \% страждають на клімактеричний синдром. Збільшення тривалості здорового життя та пролонгування віку працездатності набувають не тільки медичного, а й соціально-економічного значення, як в Україні, так i в інших європейських країнах. Тому, метою дослідження було комплексне (з залученням гіпофрізарних, яєчникових, наднирникових та тиреоїдних гормонів) гормональне обстеження жінок пери- та постменопаузального віку з клімактеричним синдромом для виявлення найбільш вірогідних гормональних предикторів даної патології. Для цього у 64 жінок перименопаузального та постменопаузального віку з клімактеричними порушеннями та у 42 здорових жінок цих же вікових категорій було виконано дослідження концентрації гіпофрізарних (ЛГ, ФСГ, пролактину), яєчникових гормонів (естрадіолу, прогестерону, тестостерону), гормонів щитоподібної залози (ТТГ, трийодтиронину (Т3), тироксину (Т4)) та наднирників (ДГЕА-с, кортизолу) в плазмі крові. Гормони визначали за допомогою набору тест-систем фрipми "Immunotech" (ЧехіяФранція) радіоімунним методом. Порівняння кількісних даних двох пов'язаних груп (до та після лікування), здійснили за допомогою непараметричного критерію Вілкоксона для парних вибірок. При виявленні різниці виконували попарні порівняння груп за допомогою критерію Манна-Уітні. У жінок перименопаузального та постменопаузального віку з клімактеричним синдромом порівняно зі здоровими жінками цих же вікових груп було виявлено достовірно підвищені рівні гонадотропінів (ЛГ у 3,7 та 3,0 рази, відповідно; ФСГ у 1,6 та 1,9 разів) та знижені показники пролактину у 1,5 та 1,2 рази; естрадіолу у 1,2 та 2,2 рази та тестостерону у 2,9 та 2,4 рази. Достовірне зниження прогестерону в 1,9 рази мало місце лише у групі жінок постменопаузального віку з клімактеричним синдромом. У жінок перименопаузального та постменопаузального віку основної групи встановлено достовірне зниження (порівняно з контролем) рівня ДГЕА-с - в 1,3 та 2,2 рази, відповідно; кортизолу у 1,2 та 2,0 рази; ТТГ у 2,6 та 2,0 рази. Разом із тим, тироксин мав тенденцію до підвищення ( $p<0,05$ була дійсна лише для жінок перименопаузального віку). Таким чином, у жінок постменопаузального віку з клімактеричним синдромом гормональний дисбаланс є більш вираженим, що свідчить про глибоку атрофрію рецепторів гормоно-залежних тканин і, як наслідок, поглиблення інволютивних процесів.

Ключові слова: гормональний гомеостаз, перименопауза, постменопауза, клімактеричні порушення.

\section{ОСОБЕННОСТИ ГОРМОНАЛЬНОГО ГОМЕОСТАЗА У ЖЕНЩИН ПЕРИМЕНОПАУЗАЛЬНОГО И ПОСТМЕНОПАУЗАЛЬНОГО ВОЗРАСТА С КЛИМАКТЕРИЧЕСКИМИ НАРУШЕНИЯМИ}

\section{Васькив О.В., Григоренко А.П., Горбатюк О.Г., Шатковская А.С., Биньковская А.М.}

По данным ВОЗ сейчас на планете 46 \% женщин находятся в возрасте старше 45 лет, среди женщин Украины - это почти половина (13,2 миллиона). Из них 46-68 \% страдают от климактерического синдрома. Увеличение продолжительности здоровой жизни и пролонгации возраста работоспособности приобретают не только медицинское, но и социальноэкономическое значение, как в Украине, так и в других европейских странах. Поэтому, целью исследования было комплексное (с вовлечением гипофизарных, яичниковых, надпочечниковых и тиреоидных гормонов) гормональное обследование женщин пери- и постменопаузального возраста с климактерическим синдромом для выявления наиболее вероятных гормональных предикторов данной патологии. Для этого у 64 женщин перименопаузального и постменопаузального возраста $c$ климактерическими нарушениями и у 42 здоровых женщин этих же возрастных категорий было выполнено исследование концентрации гипофизарных (ЛГ, ФСГ, пролактина), яичниковых гормонов (эстрадиола, прогестерона, тестостерона), гормонов щитовидной железы (ТТГ, трийодтиронина (ТЗ), тироксина (Т4)) и надпочечников (ДГЭА-с, кортизола) в плазме крови. Гормоны определяли с помощью набора тест-систем фирмы "Immunotech" (Чехия-Франция) радиоиммунным методом. Сравнение количественных данных двух связанных групп (до и после лечения), осуществили с помощью непараметрического критерия Вилкоксона для парных выборок. При выявлении разницы выполняли попарные сравнения групп с помощью критерия Манна-Уитни. У женщин перименопаузального и постменопаузального возраста с климактерическим синдромом по сравнению со здоровыми женщинами этих же возрастных групп было выявлено достоверное повышение уровней гонадотропинов (ЛГ в 3,7 и 3,0 раза, соответственно; ФСГ в 1,6 и 1,9 раз) и снижение показателей пролактина в 1,5 и 1,2 раза; эстрадиола в 1,2 и 2,2 раза и тестостерона в 2,9 и 2,4 раза. Достоверное снижение прогестерона в 1,9 раза имело место только в группе женщин постменопаузального возраста с климактерическим синдромом. У женщин перименопаузального и постменопаузального возраста основной группы установлено достоверное снижение, по сравнению с контролем, уровня ДГЭА-с в 1,3 раза и 2,2 раза, соответственно; кортизола в 1,2 и 2,0 раза; ТТГ в 2,6 раза и 2,0 раза, соответственно. Вместе с тем, тироксин имел тенденцию к повышению ( $p<0,05$ была действительна только для женщин перименопаузального возраста). Таким образом, у женщин постменопаузального возраста с климактерическим синдромом гормональный дисбаланс является более выраженным, что свидетельствует о глубокой атрофии рецепторов гормонозависимых тканей и, как следствие, углублении инволютивных процессов.

Ключевые слова: гормональный гомеостаз, перименопауза, постменопауза, климактерические нарушения. 